\title{
Whole-Farm Nitrogen Balance on Western Dairy Farms ${ }^{1}$
}

\author{
R. A. Spears, ${ }^{*}$ R. A Kohn, $\dagger$ and A. J. Young* \\ *Animal, Dairy, and Veterinary Sciences Department, \\ 4815 Old Main Hill, Utah State University, \\ Logan 84322-4815 \\ †Department of Animal and Avian Sciences, \\ Animal Science Center, University of Maryland, \\ College Park 20742-2311
}

\section{ABSTRACT}

Environmental legislation has made it necessary for livestock producers to be able to quantify and adjust the $\mathrm{N}$ balance on their farms. Whole-farm $\mathrm{N}$ balance and efficiencies were computed for 41 commercial dairies in Utah and Idaho using the University of Maryland Nutrient Balancer. The average $\mathrm{N}$ balance, or unaccounted for $\mathrm{N}$, was 81 tonnes per year for the average herd size of 466 cows with $35.8 \%$ of the inputs accounted for in the outputs. The major inputs for farms that grew crops $(\mathrm{n}=23$, herd size $=284$ total cows $)$ were imported feed (57.4\% of all inputs) and nitrogen fixation (30\% of inputs). The major outputs were animal products (primarily milk and some meat, $80 \%$ of outputs). For farms that grew no crops $(n=18$, herd size $=700$ total cows), $98 \%$ of the inputs were from imported feed. Of the outputs, $57 \%$ of the $\mathrm{N}$ was in animal products and $42.9 \%$ in manure and compost. Whole-farm balance per product for those farms that grew crops was most affected by herd $\mathrm{N}$ utilization efficiency ( $\mathrm{kg}$ feed $\mathrm{N}$ per $\mathrm{kg}$ product $\mathrm{N}$ ), crop $\mathrm{N}$ utilization efficiency, and availability of manure $\mathrm{N}$ applied to crops, while manure $\mathrm{N}$ storage efficiency was of lesser importance. For farms that grew no crops, whole-farm $\mathrm{N}$ balance per product was most affected by herd $\mathrm{N}$ utilization efficiency and manure $\mathrm{N}$ storage efficiency. Maximizing conversion of feed $\mathrm{N}$ to product $\mathrm{N}$ was the best way to reduce wholefarm $\mathrm{N}$ balance.

(Key words: nitrogen balance, commercial dairies, western United States)

\footnotetext{
Abbreviation key: CNMP = comprehensive nutrient management plan, HNUE = herd nitrogen utilization efficiency, $\mathbf{M N S E}=$ manure nitrogen storage efficiency .

Received June 18, 2002.

Accepted April 24, 2003.

Corresponding author: A. J. Young; e-mail: alleny@ext.usu.edu.

${ }^{1}$ This research was supported by SARE grant No. SW99-024, and by the Utah Agricultural Experiment Station, Utah State University, Logan, Utah 84322-4810. Approved as journal paper no. 7434.
}

\section{INTRODUCTION}

The dairy industry, as well as other livestock enterprises, has been identified as a potential contributor to point and nonpoint source environmental pollution. It has been reported for the U.S. (Howarth et al., 2002) and Europe (van Egmond et al., 2002) that the main sources of reactive $\mathrm{N}$ in the environment are fertilizers and manure. The $\mathrm{N}$ in urine (more than half of the total $\mathrm{N}$ excreted) is quickly converted into ammonia by urease in the environment (Tamminga, 1992). Ammonia may be volatilized to the atmosphere and subsequently transferred through several environmental reservoirs contributing to reduced atmospheric visibility and particle matter, soil acidity, nitrate pollution of ground water, and eutrophication of streams, lakes, and estuaries (Galloway et al., 2002). Ammonia in soil is converted into nitrate $\left(\mathrm{NO}_{3}-\mathrm{N}\right)$ that may leach into the groundwater or runoff into surface water as well as provide fertilizer for crops (Tamminga, 1992; Nelson, 1999). Concern arises regarding the $\mathrm{N}$ content in manure and its effects on groundwater, surface water, and air as it leaves the farm (Koelsch and Lesoing, 1999). In an effort to curb the detrimental effects of these potential environmental contaminates, the USDA and EPA have established that most animal feeding operations must develop a comprehensive nutrient management plan (CNMP) (US Department of Agriculture, 1999). It is difficult to measure the various $\mathrm{N}$ losses from farms on a routine basis, and strategies to control one type of loss (e.g., volatilization) often lead to increases in a different loss (e.g., leaching). Thus, wholefarm $\mathrm{N}$ balance (total farm $\mathrm{N}$ inputs minus $\mathrm{N}$ exports in products) is often considered as a means to estimate unaccounted for $\mathrm{N}$ that can become a hazard to the environment (Kohn et al., 1997). When this method effectively reduces whole-farm $\mathrm{N}$ balance, it not only benefits the producer from an environmental standpoint, but may also help producers comply with new environmental regulations.

Several researchers have examined ways of lowering overall farm N balance (Aarts et al., 1992; Dou et al., 
1996; and Kohn et al., 1997). One method of lowering excess $\mathrm{N}$ produced on the farm is by ration manipulation so that protein in the ration is utilized more efficiently, thereby reducing potential N loss (Van Vuuren et al., 1993; Van Horn et al., 1994; Vagnoni and Broderick, 1997). If this method could effectively reduce wholefarm $\mathrm{N}$ balance, it would not only benefit the producer from an environmental standpoint, but could also favorably improve dairy economics.

A spreadsheet model called the Maryland Nutrient Balancer (Kohn, 2001), based on the same principles as the worksheets developed by Dou et al. $(1996,1998)$, was developed to account for whole-farm $\mathrm{N}$ and $\mathrm{P}$ balances by quantifying all forms of $\mathrm{N}$ and $\mathrm{P}$ coming onto the farm as well as leaving the farm. By tracking $\mathrm{N}$ from the time it comes onto the farm to when it leaves, producers gain a better understanding of whole-farm $\mathrm{N}$ dynamics. This spreadsheet allows producers to determine the nutrient balance and also to look at "what if" scenarios for making management decisions.

Most of the research conducted on whole-farm $\mathrm{N}$ balance has been done with either computer models (Aarts et al., 1992; Kohn et al., 1997; Kuipers et al., 1999; Wang et al., 2000) or case studies involving 1 (Bacon et al., 1990; Dou et al., 1996; Van Horn et al., 1996; Klausner et al., 1998) or 2 dairies (Dou et al., 1998) and none have been carried out in the western United States Koelsch and Lesoing (1999) reported whole-farm balances for 33 beef and swine confinement livestock operations in Nebraska, but no dairy. There is a need to better understand factors that affect $\mathrm{N}$ balance on dairy farms.

The objectives of this study were to: 1) determine whole-farm $\mathrm{N}$ balance of commercial dairies in the Intermountain West, and 2) determine the relative contributions of the herd, manure storage, and crop production components to differences in whole-farm $\mathrm{N}$ balance. The P balance of these same farms is the focus of a companion paper (Spears et al., 2003).

\section{MATERIALS AND METHODS}

\section{Data and Sample Collection}

Data were collected from 41 dairy farms (34 farms with Holstein and 7 farms with Jersey cows as the predominant breed) selected from 7 counties in Utah and 6 counties in Idaho. Farms were selected from counties that had at least 5000 dairy cows (Idaho Agricultural Statistics Service, 1999; Utah Agricultural Statistics Service, 1999). Within each county, producers were identified who were members of the DHI and willing to cooperate in the study. On 23 farms, one or more crops were grown, while on 18 farms all feedstuffs were purchased. Farms that grew crops bought 1.3 to $92.8 \%$ of their feed and used 5 to $100 \%$ of their manure onfarm, while farms that did not grow crops exported all their manure.

Producers were initially contacted by phone, and then sent a letter outlining their involvement in the project. Producers were subsequently interviewed face-to-face to collect the information needed for the Maryland Nutrient Balancer (Kohn, 2001). The program was used to create a whole-farm $\mathrm{N}$ balance for each farm. Feed data were gathered from producer records which included actual receipts, ration sheets, and nutritional information directly obtained from their consultant. Tons of feed and fertilizer purchased was converted to tons of $\mathrm{N}$ using actual feed $\mathrm{CP}$ content and fertilizer $\mathrm{N}$ analysis provided by the farmer, when available, or using National Research Council (2001) values for feed when no analysis was available. Tons of crops grown and sold were also collected from the dairy farmer and converted to tons of $\mathrm{N}$. All analysis of data was done on a DM basis. Required inputs were: tons of purchased feed and fertilizer, tons of crops grown and sold, number of cows purchased and sold, tons of manure exported and its $\mathrm{N}$ and $\mathrm{P}$ content, and annual milk weights sold. Production characteristics such as milk protein percentage $(\mathrm{CP})$, rolling herd average milk, and cow and heifer numbers were also required inputs. An average number of animals for the whole year were used to determine the number of cows and heifers. Only one dairy contracted all heifer raising off-farm.

Nutrient inputs and outputs were reported for all farms for January through December 1999 except for one farm that underwent a major change of focus in 1999. The time period of June 1999 through May 2000 was reported for this farm. This farm was left in the analysis because the data included a complete year, overlapped 6 mo of the collection period for the other farms, and analysis could not detect it as an outlier. All other farms changed little during the data collection period. Farm information and manure samples were collected in the summer and fall of 2000 in order to have complete information for the 1999 year.

Five to 10 subsamples of stored manure (the number varying depending on farm size) were randomly collected from each storage facility on each farm and combined into a composite sample. Samples of manure in piles were taken from 6 to 8 inches into the pile at various sites ( $\mathrm{n}=3$ to 5 samples per pile) in order to obtain a representative sample. Samples were immediately frozen and stored for later analysis of $\mathrm{N}$ content. Total tons of manure coming out of storage were estimated from Natural Resources Conservation Service values (U.S. Department of Agriculture-NRCS, 1992) and combined with the $\mathrm{N}$ concentration of the manure 
Table 1. Calculations used by the Maryland Nutrient Balancer program.

\begin{tabular}{|c|c|}
\hline Efficiency & Calculation \\
\hline $\mathrm{N}$ inputs, $\mathrm{kg}$ & $\begin{array}{l}\text { Imported feed } \mathrm{N}+\text { imported bedding } \mathrm{N}+\text { imported animals } \\
\mathrm{N}+\text { imported fertilizer } \mathrm{N}+\text { legume fixation } \mathrm{N}\end{array}$ \\
\hline $\mathrm{N}$ outputs, $\mathrm{kg}$ & $\begin{array}{l}\mathrm{N} \text { in animal products }+\mathrm{N} \text { in cash crops }+\mathrm{N} \text { in exported } \\
\text { manure and compost }\end{array}$ \\
\hline $\begin{array}{l}\text { Whole-farm } \mathrm{N} \text { balance (or } \\
\text { actual unaccounted } \mathrm{N} \text { ), kg }\end{array}$ & $\begin{array}{l}\text { Total } \mathrm{N} \text { input-total } \mathrm{N} \text { output (a lower balance represents } \\
\text { less unaccounted for } \mathrm{N} \text { ) }\end{array}$ \\
\hline Herd $\mathrm{N}$ utilization efficiency & $\mathrm{Kg} \mathrm{N}$ in product (milk and meat)/Kg $\mathrm{N}$ in feed \\
\hline Manure $\mathrm{N}$ produced, $\mathrm{kg}$ & Animal $\mathrm{N}$ intake- $\mathrm{N}$ in animal product (milk and meat) \\
\hline Manure N storage efficiency & $\begin{array}{l}\text { Total } \mathrm{kg} \text { manure } \mathrm{N} \text { that is exported from farm or applied to } \\
\text { crops/manure } \mathrm{N} \text { produced }\end{array}$ \\
\hline Manure $\mathrm{N}$ available to crop, $\mathrm{kg}$ & $\begin{array}{l}\text { Kg manure N applied-N field loss (\% loss to volatilization } \\
\text { due to timing of incorporation into soil and frequency and } \\
\text { seasonality of application. Range is from } 20 \text { to } 88 \% \text { ) }\end{array}$ \\
\hline Availability of applied manure & Manure $\mathrm{N}$ available to crop/manure $\mathrm{N}$ applied \\
\hline Crop $\mathrm{N}$ utilization efficiency & $\begin{array}{l}\text { Total } \mathrm{N} \text { in crop/Total } \mathrm{N} \text { available to crop (sum of available } \\
\text { manure and fertilizer } \mathrm{N} \text { ) }\end{array}$ \\
\hline Manure $\mathrm{N}$ applied, kg & $\begin{array}{l}\text { Manure } \mathrm{N} \text { stored + imported manure } \mathrm{N} \text { (no farms imported } \\
\text { in this study)-exported manure } \mathrm{N}\end{array}$ \\
\hline
\end{tabular}

so that total tonnes of $\mathrm{N}$ coming out of storage could be compared with the amount going into storage.

\section{Laboratory Procedures}

Stored manure samples were analyzed for DM by drying in a forced air oven at $60^{\circ} \mathrm{C}$, ground through a 1 -mm mesh screen in a Wiley Mill, then further dried at $105^{\circ} \mathrm{C}$. The DM content was then determined based on final weight of the sample (AOAC, 1984). Samples dried at $60^{\circ} \mathrm{C}$ were analyzed for $\mathrm{N}$ by the combustion method (AOAC, 1996) using a Carlo Erba Elantech NA 2100 Protein Nitrogen Analyzer (ThermoQuest, Italia S.p.A., Milan, Italy). Nitrogen content on an absolute DM basis was used in data analysis.

\section{Calculations Within the Maryland Nutrient Balancer}

The Maryland Nutrient Balancer (Kohn, 2001) calculated summaries and several efficiencies that were used in later analysis. These efficiencies and the methods used to calculate them are shown in Table 1.

\section{Statistical Analysis}

The data were analyzed as a completely randomized design with individual farm as the experimental unit. Descriptive statistics were analyzed from participating herds. All whole-farm $\mathrm{N}$ balances were converted to a per kilogram of milk and meat $\mathrm{N}$ basis (balance per product) prior to analysis to eliminate the effect of farm size on farm balance. A multivariate regression model was developed with whole-farm $\mathrm{N}$ balance per product as the dependent variable and herd nitrogen utilization efficiency (HNUE), manure nitrogen storage efficiency (MNSE), and crop $\mathrm{N}$ utilization efficiencies (Table 1) as independent variables. Univariate regression models with whole-farm $\mathrm{N}$ balance per product regressed on HNUE, MNSE, whole-farm $\mathrm{P}$ balance per product (Spears et al., 2003), imported feed per product, milk production, herd size, manure exported per product, imported fertilizer per product, total $\mathrm{N}$ available to crop, total crop $\mathrm{N}$, availability of manure $\mathrm{N}$ applied, and uptake of available $\mathrm{N}$ were analyzed to determine the relative importance of the components of each subsystem. Herd $\mathrm{N}$ utilization efficiency had the greatest impact on whole-farm $\mathrm{N}$ balance per product, therefore, factors influencing HNUE were analyzed further. Univariate regression of the dependent variable of HNUE was performed on the independent variables of herd $\mathrm{P}$ utilization efficiency (Spears et al., 2003), milk production per cow, herd size, and imported feed per product. Breed of cow did not significantly affect dependent variables; therefore, herds from both breeds were combined in the analyses. Regression analysis and ANOVA were performed in SAS (1996) using Proc GLM. Variables considered to be significantly different $(P<0.05)$.

\section{RESULTS AND DISCUSSION}

\section{Description of Farms}

Herds involved in the study provided a wide range of measured variables and, therefore, calculated efficiencies (Tables 2 and 3). Milk production per cow ranged from $3402 \mathrm{~kg} /$ year to $13,864 \mathrm{~kg} /$ year with an average of $10,254 \mathrm{~kg} /$ year, well above the year 2000 national average of $8276 \mathrm{~kg} /$ year (National Agricultural Statistics Service, 2001), and consistent with the average $(10,143 \mathrm{~kg} / \mathrm{year})$ for herds in this region (Rocky Mountain DHIA Annual Summary, 2000). Herd size ranged from 57 cows to 1960 cows and averaged 466 
Table 2. Summary of selected variables for farms that grew any crops $(n=23)$.

\begin{tabular}{lcccc}
\hline Parameter & Mean & SD & Minimum & Maximum \\
\hline Total herd size of cows & 284 & 297 & 57 & 1450 \\
Herd size of heifers & 242 & 233 & 35 & 1125 \\
Milk production, kg per cow $^{\text {Milk protein, \% }}$ & 9,732 & 2,405 & 3,402 & 12,659 \\
Herd N utilization efficiency $^{1}$ & 3.33 & 0.293 & 2.90 & 4.02 \\
Manure storage efficiency $^{2}$ & 0.203 & 0.052 & 0.126 & 0.362 \\
Crop N utilization efficiency $^{3}$ & 0.357 & 0.144 & 0.064 & 0.659 \\
\hline
\end{tabular}

\footnotetext{
${ }^{1} \mathrm{Kg} \mathrm{N}$ in product (milk and meat)/kg N in feed.

${ }^{2}$ Total amount of manure $\mathrm{N}$ that is exported from farm or applied to crops/ $\mathrm{N}$ in excreted manure (calculated by mass balance equation that is $\mathrm{N}$ in feed- $\mathrm{N}$ in product).

${ }^{3}$ Total $\mathrm{N}$ in crop/Total $\mathrm{N}$ available to crop (sum of available manure and fertilizer $\mathrm{N}$ ).
}

cows. Herd $\mathrm{N}$ utilization efficiency ranged from 0.126 to 0.362 with an average of 0.213 , suggesting that $21.3 \%$ of all $\mathrm{N}$ fed to the herd (cows and replacement heifers) was converted into either milk or meat $\mathrm{N}$ based on the law of mass conservation used by the Balancer to make this calculation. Close to half of the farms in this study (44\%) imported all feed.

Farms were further divided into those that grew any crops (Table 2) and those that grew no crops (Table 3). Farms that grew crops averaged 284 cows with a range of 57 to 1450 cows. Milk production averaged $9732 \mathrm{~kg} /$ cow per year with a range of 3402 to $12,659 \mathrm{~kg} / \mathrm{cow}$ per year. Average HNUE was $20.3 \%$, MNSE was $35.7 \%$ and crop $\mathrm{N}$ utilization was $114 \%$. For farms that grew no crops, average herd size was 700 cows with a range of 62 to 1960 . Milk production averaged $10,922 \mathrm{~kg} / \mathrm{cow}$ per year with a range of 6568 to $13,864 \mathrm{~kg} / \mathrm{cow}$ per year. Average HNUE was 22.5\%, MNSE was 26.4\%, and crop $\mathrm{N}$ utilization efficiency was 0.0 (no crops were grown). The average HNUE for farms that grew no crops was about 2\% higher and the MNSE was about 9\% lower ( $P=0.063$ for difference between the two groupings) than farms that grew crops.

\section{Whole-Farm N Balance}

Whole-farm $\mathrm{N}$ balance for dairies in the West was consistent with other studies in that imported feed was the single largest $\mathrm{N}$ input and animal products, milk and meat, were the largest source of output (Table 4). Farms that grew crops had inputs from fertilizer for crop application and legume fixation from alfalfa that were not present for those farms that grew no crops. Those farms that grew no crops had $98 \%$ of their inputs as imported feed because they had no need for fertilizer and had no crops for legume fixation. These farms also exported a greater amount of manure and compost because they had little or no land for application. Herd size was significantly larger for those farms that grew no crops, but on a per animal basis, there was little difference in whole-farm $\mathrm{N}$ balance between the two groups.

Average whole-farm $\mathrm{N}$ balance for all farms, expressed as tonnes of $\mathrm{N}$ per year, is shown in Table 4. Our results show a positive whole-farm $\mathrm{N}$ balance, indicating that more $\mathrm{N}$ is coming onto farms than is being accounted for in the sale of product (mostly milk, some meat), exported crops, and exported manure. Previously reported whole-farm $\mathrm{N}$ efficiencies $(\mathrm{N}$ in total outputs divided by $\mathrm{N}$ in total inputs $\times 100)$ ranged from 15\% (Aarts et al., 1992) to $46 \%$ (Bacon et al., 1990). The average whole-farm $\mathrm{N}$ utilization efficiency (output/input) for the farms in this study was $35.8 \%$. This means that $64.2 \%$ of the $\mathrm{N}$ coming onto the farm could not be accounted for in product, cash crops or compost and manure. A large portion of this $\mathrm{N}$ was probably lost

Table 3. Summary of selected variables for farms that grew no crops $(n=18)$.

\begin{tabular}{lcccc}
\hline Parameter & Mean & SD & Minimum & Maximum \\
\hline Herd size of cows & 700 & 586 & 62 & 1960 \\
Herd size of heifers & 404 & 396 & 0 & 1400 \\
Milk production, kg per cow $^{\text {Milk protein, \% }}$ & 10,922 & 2,047 & 6,568 & 13,864 \\
Herd N utilization efficiency $^{1}$ & 3.27 & 0.295 & 2.90 & 3.85 \\
Manure storage efficiency $^{2}$ & 0.225 & 0.041 & 0.168 & 0.290 \\
Crop N utilization efficiency $^{3}$ & 0.264 & 0.168 & 0.060 & 0.680 \\
\hline
\end{tabular}

\footnotetext{
${ }^{1} \mathrm{Kg} \mathrm{N}$ in product (milk and meat)/kg $\mathrm{N}$ in feed.

${ }^{2}$ Total amount of manure $\mathrm{N}$ that is exported from farm or applied to crops/ $\mathrm{N}$ in excreted manure (calculated by mass balance equation that is $\mathrm{N}$ in feed- $\mathrm{N}$ in product).

${ }^{3}$ Total $\mathrm{N}$ in crop/Total $\mathrm{N}$ available to crop (sum of available manure and fertilizer $\mathrm{N}$ ).
} 
Table 4. Average whole-farm $\mathrm{N}$ balance per farm, expressed as tonnes of N/year, as calculated by the Maryland Nutrient Balancer $(\mathrm{n}=41)$. Average herd size was 466 cows and milk production was $10,254 \mathrm{~kg} /$ cow per year. Nitrogen balance is the difference between inputs and outputs.

\begin{tabular}{lcrrr}
\hline Variable & Average & \multicolumn{1}{l}{ SD } & Minimum & Maximum \\
\hline Nitrogen inputs & 125.83 & 134.33 & 12.66 & 670.71 \\
Imported feed & 105.99 & 134.56 & 4.49 & 659.86 \\
Imported bedding & 1.31 & 2.19 & 0.00 & 12.80 \\
Imported animals & 0.89 & 2.10 & 0.00 & 8.85 \\
Imported fertilizer & 4.85 & 10.51 & 0.00 & 63.40 \\
Legume fixation & 12.81 & 21.01 & 0.00 & 240.97 \\
Nitrogen outputs, kg & 45.01 & 55.50 & 5.42 & 119.90 \\
Animal products & 28.48 & 30.68 & 3.25 & 18.42 \\
Cash crops & 1.04 & 3.35 & 0.0 & 148.63 \\
Manure/compost & 15.49 & 30.06 & 0.0 & 455.17 \\
N balance (potential loss) & 80.84 & 85.98 & 6.40 & \\
Output/input, \% & 35.8 & & &
\end{tabular}

through volatilization and represents a major portion of the $\mathrm{N}$ flow on these dairies. Loss of $\mathrm{N}$ through volatilization needs to be controlled as more states begin to enact laws regarding odor from dairies. In addition, a source of $\mathrm{N}$ loss could be the drying step used to analyze manure samples. Heating the sample would volatilize any remaining ammonia $\mathrm{N}$ and underestimate the $\mathrm{N}$ content of the sample. This loss may or may not be significant because most of the ammonia may have all ready volatized before the sample was taken (R. Kohn, personal communication). Also, none of the dairies incorporated manure in less than $7 \mathrm{~d}$. This would have allowed any remaining ammonia to no longer be available for crops. The values in this paper are based on the assumption that minimal amounts of $\mathrm{N}$ were lost due to drying the sample prior to analysis.

One problem with comparing efficiencies between studies is that not all studies use the same categories for inputs and outputs. For example, the farm analyzed by Bacon et al. (1990) showed a high whole-farm N utilization efficiency, but they did not make allowance for $\mathrm{N}$-fixation by legumes.

Average whole-farm $\mathrm{N}$ balance was then subdivided and computed separately for farms that grew crops and those that did not (Table 5) because the amount of land base for crops can affect interpretation of whole-farm $\mathrm{N}$ balances. Most of the farms reported in the literature were small dairies with sufficient land to have an outlet for manure produced on the farm (Dou et al., 1996; Van Horn et al., 1996; Klausner et al., 1998). Dairies in the western United States are unique because of larger herd size and the fact that many dairies include only enough land base to house the animals plus a buffer around the dairy (i.e., less than 0.4 ha per cow). On farms where crops were grown, total tonnes/year of unaccounted for $\mathrm{N}$ was less than on those farms where no crops were grown (Table 5), primarily due to differences in herd size. Increased inputs of $\mathrm{N}$ associated with crop production increased the total $\mathrm{N}$ balance on farms that grew crops and made the output/input percent on farms

Table 5. Average of whole-farm $\mathrm{N}$ balance per farm for those farms that grew crops $(\mathrm{n}=23)$ and those farms that grew no crops $(\mathrm{n}=18$ ), expressed as tonnes N/year or $\mathrm{kg} N$ /animal, as calculated by the Maryland Nutrient Balancer. Nitrogen balance is the difference between inputs and outputs.

\begin{tabular}{|c|c|c|c|c|}
\hline \multirow[b]{2}{*}{ Variable } & \multicolumn{2}{|c|}{ Grew crops } & \multicolumn{2}{|c|}{ Grew no crops } \\
\hline & $\begin{array}{l}\text { tonnes } \\
\text { per yr }\end{array}$ & $\begin{array}{l}\text { kg per } \\
\text { animal }^{1}\end{array}$ & $\begin{array}{l}\text { tonnes } \\
\text { per year }\end{array}$ & $\begin{array}{l}\text { kg per } \\
\text { animal }^{1}\end{array}$ \\
\hline Nitrogen inputs & 76.36 & 188.55 & 189.68 & 210.29 \\
\hline Imported feed & 43.82 & 108.19 & 185.93 & 206.13 \\
\hline Imported bedding & 0.75 & 1.86 & 2.02 & 2.24 \\
\hline Imported animals & 0.23 & 0.57 & 1.74 & 1.93 \\
\hline Imported fertilizer & 8.66 & 21.39 & 0.0 & 0.00 \\
\hline Legume fixation & 22.88 & 56.50 & 0.0 & 0.00 \\
\hline Nitrogen outputs & 21.81 & 53.85 & 74.87 & 83.01 \\
\hline Animal products & 17.42 & 43.01 & 42.75 & 47.40 \\
\hline Cash crops & 1.85 & 4.58 & 0.0 & 0.00 \\
\hline Manure/compost & 2.54 & 6.26 & 32.12 & 35.61 \\
\hline $\mathrm{N}$ balance (potential loss) & 54.54 & 134.68 & 114.82 & 127.29 \\
\hline Output/input, \% & 28.6 & - & 39.5 & - \\
\hline
\end{tabular}

${ }^{1}$ Animals includes cows plus half the number of heifers (i.e., 2 heifers $=1$ cow). 
Table 6. Multiple regression analysis results of whole-farm nitrogen $(\mathrm{N})$ balance per $\mathrm{kg} \mathrm{N}$ in milk and meat, for farms that grew at least one crop $\left(\mathrm{R}^{2}=0.903\right)$.

\begin{tabular}{lclrc}
\hline Factor & Estimate & SE & $\%$ SS & $P$-value \\
\hline Intercept & 10.5 & 0.577 & & $<0.0001$ \\
Herd N utilization efficiency & -17.08 & 2.499 & 54.2 & $<0.0001$ \\
Crop uptake of available N & -2.02 & 0.377 & 33.4 & $<0.0001$ \\
Availability of manure N applied to crops & -3.29 & 1.237 & 8.2 & 0.016 \\
Manure N storage efficiency & -1.80 & 0.944 & 4.2 & 0.073 \\
\hline
\end{tabular}

that grew no crops better by $11 \%$. The average herd size for farms that grew no crops was nearly 2.5 -fold higher than for farms that grew crops, but when the data were corrected for number of animals per farm (Table 5), the amount of unaccounted for $\mathrm{N}$ was slightly higher per animal for farms that grew crops compared with farms that grew no crops. On a whole-farm basis, the higher positive $\mathrm{N}$ balance makes these farms a greater potential threat to the environment (especially odor) than those that grew crops. In this study, farms without crops typically had a larger herd size, higher milk production per cow, greater tonnes of manure exported, and no imported fertilizer or legume fixation.

\section{Effects of Subsystems on Whole-Farm Balance/Product}

A multiple regression analysis was used to determine the relative impact of the subsystems (herd, crops, and manure management) on whole-farm balance per product (tonnes unaccounted for $\mathrm{N}$ per tonne milk and meat $\mathrm{N})$. The multiple regression analysis for farms that grew crops is shown in Table 6. A total of $90 \%$ of the variation in farm nitrogen balance was explained by the efficiencies of the farm components. Herd N utilization efficiency explained $54.2 \%$ and crop uptake of available $\mathrm{N}$ explained $33.4 \%$ of the observed variation. Estimated availability of manure $\mathrm{N}$ applied to crops and MNSE explained about $12 \%$ of the variation among farms. Even though MNSE was the least important of the subsystems in this model, it is still a significant factor when determining how to decrease whole-farm $\mathrm{N}$ balance per product (see Table 8). These results are in agreement with those of a sensitivity analysis on mod- eled dairy farms reported by Kohn et al. (1997). Aarts et al. (1992) also found improving HNUE to be important in decreasing overall farm $\mathrm{N}$ balance. Wang et al. (2000) estimated that increasing forage yield by $50 \%$, compared with yields from their base herd, would decrease whole-farm N mass balance by $29 \%$. Paul et al. (1998) suggested that increasing HNUE not only decreased $\mathrm{N}$ in the manure, but the $\mathrm{N}$ might also be less susceptible to volatilization and more likely to be incorporated by crops. Again, results from this study support the concept that the most important method to improve whole-farm $\mathrm{N}$ balance is improved HNUE.

The multiple regression analysis of whole-farm $\mathrm{N}$ balance per product on farm subsystems for farms that did not grow crops is shown in Table 7. The model accounted for $97 \%$ of the variation in whole-farm $\mathrm{N}$ balance per product. Herd $\mathrm{N}$ utilization efficiency accounted for 50.6\% and MNSE accounted for $49.4 \%$ of the observed variation. For farms that grew no crops, MNSE became more significant than for farms that grew crops because with no land base there were no sources of variability except for the $\mathrm{N}$ in manure and compost. In both farm groupings, HNUE accounted for a significant portion of the variation in whole-farm $\mathrm{N}$ balance per product.

On farms where crops were grown (Table 8), univariate regression analysis of whole-farm $\mathrm{N}$ balance per product with crop $\mathrm{N}$ utilization efficiency was correlated $\left(\mathrm{R}^{2}=0.324, P=0.005\right.$; negative slope). It was also interesting that on some farms, crop $\mathrm{N}$ utilization efficiency was greater than 1.0, meaning $\mathrm{N}$ in the crop was greater than the $\mathrm{N}$ available for the crop as calculated by the program. We do not have enough data to determine the reason for this, but some possibilities are that $\mathrm{N}$ fixation

Table 7. Multiple regression analysis results of whole-farm nitrogen (N) balance per $\mathrm{kg} \mathrm{N}$ in milk and meat for farms that did not grow any crops $\left(n=17^{1} ; R^{2}=0.97\right)$.

\begin{tabular}{lclll}
\hline Factor & Estimate & SE & $\%$ SS & $P$-value \\
\hline Intercept & 6.85 & 0.226 & - & $<0.0001$ \\
Herd N utilization efficiency & -14.32 & 0.938 & 50.6 & $<0.0001$ \\
Manure N storage efficiency & -3.41 & 0.226 & 49.4 & $<0.0001$ \\
\hline
\end{tabular}

${ }^{1}$ One herd was excluded from the analysis because it was an outlier. The $\mathrm{R}^{2}$ with that herd included was 0.841 . 
Table 8. Relationship of selected variables to whole-farm nitrogen $(\mathrm{N})$ balance per $\mathrm{kg} \mathrm{N}$ in milk and meat, for farms that grew at least one crop $(\mathrm{n}=23)$ and farms that grew no crops $(\mathrm{n}=18)$.

\begin{tabular}{|c|c|c|c|c|}
\hline \multirow[b]{2}{*}{ Independent variable } & \multicolumn{2}{|c|}{ Grew crops } & \multicolumn{2}{|c|}{ Grew no crops } \\
\hline & $\mathrm{R}^{2}$ & $P$-value & $\mathrm{R}^{2}$ & $P$-value \\
\hline Herd $\mathrm{N}$ utilization ${ }^{1}$ & $0.671^{4}$ & $<0.0001$ & $0.493^{4}$ & 0.001 \\
\hline Manure N storage efficiency ${ }^{2}$ & $0.423^{4}$ & 0.001 & $0.304^{4}$ & 0.018 \\
\hline Whole-farm $\mathrm{P}$ balance ${ }^{3} / \mathrm{P}$ product & 0.142 & 0.076 & 0.254 & 0.033 \\
\hline Imported feed/product & 0.213 & 0.026 & 0.488 & 0.001 \\
\hline Milk production/cow & $0.005^{4}$ & 0.742 & $0.042^{4}$ & 0.412 \\
\hline Herd size & $0.089^{4}$ & 0.168 & $0.026^{4}$ & 0.520 \\
\hline Manure exported/product & $0.043^{4}$ & 0.341 & $0.240^{4}$ & 0.039 \\
\hline Imported fertilizer/product & 0.065 & 0.239 & - & - \\
\hline Total $\mathrm{N}$ available crop & 0.140 & 0.078 & - & - \\
\hline Total crop N & 0.051 & 0.299 & - & - \\
\hline Availability of manure $\mathrm{N}$ applied & $0.022^{4}$ & 0.496 & - & - \\
\hline Crop N utilization efficiency & $0.324^{4}$ & 0.005 & - & - \\
\hline
\end{tabular}

by legumes was underestimated (alfalfa is the principal crop in this region), or there was carryover of $\mathrm{N}$ in the soil from previous years that was unaccounted for. The program only looked at the balance for a single time period, not multiple years.

On farms where crops were not grown, exported manure per product was negatively correlated with wholefarm N balance $\left(\mathrm{R}^{2}=0.24, P=0.039\right.$; Table 8$)$. This makes sense because exported manure or compost is one of the few options available to these farms for improvement of whole-farm N balance. Koelsch and Lesoing (1999) proposed exporting manure as an efficient means of lowering farm $\mathrm{N}$ balance. Although this has been shown to lower whole-farm $\mathrm{N}$ balance, the $\mathrm{N}$ in the manure does not simply disappear when taken off farm. As noted by Kohn et al. (1997), caution must be taken not to see this as a quick fix. For a single herd that does not grow crops, this could be an effective way to balance a CNMP, but it could be a problem from a watershed perspective. Univariate regression analysis of MNSE with whole-farm $\mathrm{N}$ balance per product for farms that grew no crops was negatively correlated $\left(R^{2}\right.$ $=0.304, P=0.018$; Table 8). Again, manure handling becomes important because they have fewer options and must make better use of the subsystems available to them.

Whole-farm $\mathrm{P}$ balance per product was correlated with whole-farm $\mathrm{N}$ balance per product for farms that grew no crops $\left(\mathrm{R}^{2}=0.254, P=0.033\right.$; Table 8$)$ and showed a trend $(P=0.076)$ for farms that grew crops. Many states are passing regulations based on soil $\mathrm{P}$ levels, rather than $\mathrm{N}$ levels and this study suggests that improvement in the whole-farm balance of one nutrient is associated with improvement of the other.

\section{Herd N Utilization Efficiency}

Herd $\mathrm{N}$ utilization efficiency was significantly related to whole-farm $\mathrm{N}$ balance per product for both farms that did and did not grow crops (Table 8); therefore, factors influencing HNUE were analyzed. When all dairies in this study were analyzed together, herd size was positively correlated with the HNUE $\left(\mathrm{R}^{2}=0.11, P\right.$ $=0.036)$. Farms that had more than 500 cows $(\mathrm{n}=14)$ had a significantly higher HNUE $(23.5 \% \mathrm{SD}=4.2)$ than farms that had less than 500 cows $(20.2 \% \mathrm{SD}=4.9)(\mathrm{n}$ $=27$ ). However, when the farms were analyzed based on whether a farm did or did not grow crops, there was no relationship between HNUE and herd size (Table 9), probably due to sample size. Larger farms appeared to be more consistent in converting feed $\mathrm{N}$ into product than smaller farms. Increased cow numbers may allow for better grouping strategies to be employed in herd management. St-Pierre and Thraen (1999) showed that optimal grouping strategy would increase herd efficiency by providing nutrients where they were most needed. The larger farms in this study did have increased numbers of groupings of cows compared with smaller farms. Interestingly, the number of heifers per farm was not related to whole-herd $\mathrm{N}$ balance or HNUE for farms that grew or did not grow crops (data not shown). However, for farms that did not grow crops, the ratio of heifers to cows per farm showed a trend relative to either whole-farm $\mathrm{N}$ balance per product $(P$ $=0.059)$ or HNUE $(P=0.051$; negative slope, Table 9$)$. This is interesting because many dairies with little land base are considering contracting the raising of their heifers off-farm. This data suggests that reducing the number of heifers relative to the number of cows on a 
Table 9. Relationship of selected independent variables to herd $\mathrm{N}$ utilization efficiency ${ }^{1}$ for farms that grew at least one crop $(n=23)$ and farms that grew no crops $(n=18)$.

\begin{tabular}{|c|c|c|c|c|}
\hline \multirow[b]{2}{*}{ Independent variable } & \multicolumn{2}{|c|}{ Grew crops } & \multicolumn{2}{|c|}{ Grew no crops } \\
\hline & $\mathrm{R}^{2}$ & $P$-value & $\mathrm{R}^{2}$ & $P$-value \\
\hline Number of heifers per cow & 0.032 & 0.415 & $0.217^{3}$ & 0.051 \\
\hline Herd size & 0.103 & 0.135 & 0.068 & 0.296 \\
\hline Milk production/cow & 0.099 & 0.143 & 0.281 & 0.024 \\
\hline Herd $\mathrm{P}$ utilization efficiency ${ }^{2}$ & 0.539 & $<0.0001$ & 0.186 & 0.074 \\
\hline Breed & 0.015 & 0.583 & 0.046 & 0.393 \\
\hline Imported feed/product & $0.097^{3}$ & 0.147 & $0.980^{3}$ & $<0.0001$ \\
\hline
\end{tabular}

${ }^{1}$ Herd $\mathrm{N}$ utilization efficiency $=\mathrm{N}$ in product (milk and meat) $/ \mathrm{N}$ in feed.

${ }^{2}$ Herd $\mathrm{P}$ utilization efficiency $=\mathrm{P}$ in product (milk and meat)/P in feed (Spears et al., 2003).

${ }^{3}$ Denotes relationship with a negative slope.

dairy would increase HNUE efficiency and decrease whole-farm $\mathrm{N}$ balance per product; both desirable goals.

There was also a positive correlation between HNUE and milk production $\left(\mathrm{R}^{2}=0.281, P=0.024\right.$; Table 9$)$ for farms that grew no crops, but no relationship for farms that grew crops. This may be a function of the slightly higher HNUE and milk per cow for farms that grew no crops compared to those farms that grew crops. It may also mean that for farms that grew no crops, maximizing conversion of feed $\mathrm{N}$ to product $\mathrm{N}$ left less $\mathrm{N}$ to be handled in manure and compost. Other studies have shown that increased HNUE was associated with a slightly negative relationship with milk yield (Dinn et al., 1998) or no relationship (Dhiman and Satter, 1997). Results from this study show that all herds that produced $13,000 \mathrm{~kg} / \mathrm{yr}$ or more had HNUEs of close to $25 \%$ suggesting that a greater proportion of consumed $\mathrm{N}$ is being used for milk and meat and less for maintenance of the animal.

Herd P utilization efficiency (Spears et al., 2003) was correlated with HNUE $\left(\mathrm{R}^{2}=0.539, P \leq 0.0001\right.$; Table 9) for farms that grew crops, while farms that grew no crops showed a trend $(P=0.074)$. Although we cannot determine the reason for the difference between farms based on whether they did or did not grow crops, we suggest two possible explanations for why HPUE and HNUE might be related. The first may be related to the composition of milk. Wu et al. (2001) reported a positive relationship between milk protein and $\mathrm{P}$ concentrations. It was suggested that because phosphate bridges hold casein micelles in milk together, increased milk protein would require an increase in milk phosphorus, even though this form of $\mathrm{P}$ comprises only a small fraction of the total milk $P$. The second may be that rations properly balanced for $\mathrm{P}$ are likely balanced for protein. It is interesting to note that in a study where adjustments were made to lower whole-farm $\mathrm{N}$ balance (Bacon et al., 1990), whole-farm P balance was also decreased.
Imported feed $\mathrm{N}$ per product was not correlated with HNUE ( $P=0.147$; Table 9$)$ for farms that grew crops, but was correlated $\left(\mathrm{R}^{2}=.98, P \leq 0.0001\right.$; Table 9$)$ with farms that did not grow crops. This is likely due to the fact that farms that grew crops only bought enough feed to supplement the amount grown on-farm while farms that grew no crops bought all of their feed. For farms that grew feed, legume fixation/product and imported $\mathrm{N}$ fertilizer/product were more important than imported feed/product.

\section{CONCLUSIONS}

Whole-farm $\mathrm{N}$ balance for dairies in the West was consistent with other studies in that imported feed was the single largest $\mathrm{N}$ input and animal products, milk and meat, were the largest source of output (Table 4). Farms that grew crops had inputs from fertilizer for crop application and legume fixation from alfalfa that were not present for those farms that grew no crops.

Multiple regression analysis showed that whole-farm $\mathrm{N}$ balance per product was associated with HNUE, crop $\mathrm{N}$ utilization efficiency, availability of manure $\mathrm{N}$ applied to crops, and MNSE for farms that grew crops. For farms that grew no crops, HNUE and MNSE were the most important subsystems. The most important subsystem on these dairies was how efficiently a cow converted feed $\mathrm{N}$ to product $\mathrm{N}$ and should be the first concern in lowering whole-farm $\mathrm{N}$ balance per product. After HNUE is optimized, the next subsystem to optimize is crop $\mathrm{N}$ utilization efficiency. Crop selection and $\mathrm{N}$ application methods most appropriate to the area of production should be considered for this subsystem. Manure handling should not overshadow herd and crop $\mathrm{N}$ efficiencies in attempts to improve $\mathrm{N}$ balances. Regulations should be based on some measure of performance such as nutrient balance rather than on the incorporation of specific technologies such as a certain manure storage system (Lanyon, 1994). Whole-farm N 
balances are useful tools for evaluating $\mathrm{N}$ management on a dairy farm.

\section{REFERENCES}

AOAC. 1984. Official Methods of Analysis. 14th ed. Association of Official Analytical Chemists, Washington, DC.

AOAC. 1996. Official Methods of Analysis. 16th ed. Association of Official Analytical Chemists, Arlington, VA.

Aarts, H. F. M., E. E. Biewinga, and H. Van Keulen. 1992. Dairy farming systems based on efficient nutrient management. Neth. K. Agric. Sci. 40:285-299.

Bacon, S. C., L. E. Lanyon, and R. M. Schlauder, Jr. 1990. Plant nutrient flow in the managed pathways of an intensive dairy farm. Agron. J. 82:755-761.

Dhiman, T. R., and L. D. Satter. 1997. Yield response of dairy cows fed different proportions of alfalfa silage and corn silage. J. Dairy Sci. 80:2069-2082.

Dinn, N. E., J. A. Shelford, and L. J. Fisher. 1998. Use of the Cornell Net Carbohydrate and Protein System and rumen-protected lysine and methionine to reduce nitrogen excretion from lactating dairy cows. J. Dairy Sci. 81:229-237.

Dou, Z., R. A. Kohn, J. D. Ferguson, R. C. Boston, and J. D. Newbold. 1996. Managing nitrogen on dairy farms: An integrated approach. I. Model description. J. Dairy Sci. 79:2071-2080.

Dou, Z., L. E. Lanyon, J. D. Ferguson, R. A. Kohn, R. C. Boston, and W. Chalupa. 1998. An integrated approach to managing nitrogen on dairy farms: Evaluation of farm performance using the Dairy Nitrogen Planner. Agron. J. 90:573-581.

Galloway, J. N., E. B. Cowling, S. P. Seitzinger, and R. H. Socolow. 2002. Reactive nitrogen: Too much of a good thing. Ambio $31: 60-63$.

Howarth, R. W., E. W. Boyer, W. J. Pabich, and J. N. Galloway. 2002. Nitrogen use in the United States from 1961-2000 and potential future trends. Ambio 31:88-96.

Idaho Agricultural Statistics Service. 1999. Idaho county estimates. June 16. Online. Available: http://nass.usda.gov/id.

Klausner, S. D., D. G. Fox, C. N. Rasmussen, R. E. Pitt, T. P. Tylutki, P. E. Wright, L. E. Chase, and W. C. Stone. 1998. Improving dairy farm sustainability I: An approach to animal and crop nutrient management planning. J. Prod. Agric. 11:225-233.

Koelsch, R., and G. Lesoing. 1999. Nutrient balance on Nebraska livestock confinement systems. J. Dairy Sci. 82(Suppl. 2):63-71.

Kohn, R. A. Maryland nutrient balancer. 2001. Online. Available: http://www.inform.umd.edu/EdRes/Topic/AgrEnv/Manure/.

Kohn, R. A., Z. Dou, J. D. Ferguson, and R. C. Boston. 1997. A sensitivity analysis of nitrogen losses from dairy farms. J. Environ. Manag. 50:417-428.

Kuipers, A., F. Mandersloot, and R. L. G. Zom. 1999. An approach to nutrient management on dairy farm. J. Dairy Sci. 82(Suppl. 2):84-89.

Lanyon, L. E. 1994. Dairy manure and plant nutrient management issues affecting water quality and the dairy industry. J. Dairy Sci. 77:1999-2007.
National Agricultural Statistics Service. 2001. Milk production. Online. Available: http://www.usda.mannlib.cornell.edu/reports/ nassr/dairy/pmp-bb/mkpr0201.

National Research Council. 2001. Nutrient Requirements of Dairy Cattle. 7th rev. ed. Natl. Acad. Sci., Washington, DC.

Nelson, C. J. 1999. Managing nutrients across regions of the United States. J. Dairy Sci. 82(Suppl. 2):90-100.

Paul, J. W., N. E. Dinn, T. Kannangara, and L. J. Fisher. 1998. Protein content in dairy cattle diets affects ammonia losses and fertilizer nitrogen value. J. Environ. Qual. 27:528-534.

Rocky Mountain DHIA Annual Summary. 2000. Utah State University Extension and Department of Animal, Dairy and Veterinary Sciences, Utah State University, Logan, UT.

SAS/STAT User's Guide: Statistics. 1996. Version 6.12 Edition. SAS Inst. Inc., Cary, NC.

Spears, R. A., R. A. Kohn, and A. J. Young. 2003. Whole-farm phosphorus balance on western dairy farms. J. Dairy Sci. 86:688-695.

St-Pierre, N. R., and C. S. Thraen. 1999. Animal grouping strategies, sources of variation, and economic factors affecting nutrient balance on dairy farms. J. Dairy Sci. 82(Suppl. 2):72-83.

Tamminga, S. 1992. Nutrition management of dairy cows as a contribution to pollution control. J. Dairy Sci. 75:345-357.

U.S. Department of Agriculture-NRCS. 1992. Agricultural waste characteristics. Part 651 in Agricultural Waste Management Field Handbook.

U.S. Department of Agriculture. U.S. Environmental Protection Agency. 1999. Unified national strategy for animal feeding operations. Online. Available: http://www.epa.gov/owm/finafost.

Utah Agricultural Statistics Service. 1999. Annual Bulletin Pages. Cattle, Utah January 1998 (revised) \& 1999. Online. Available: http://www.nass.usda.gov/ut/Pdf/ab99/99107.pdf.

Vagnoni, D. B., and G. A. Broderick. 1997. Effects of supplementation of energy of ruminally undegraded protein to lactating cows fed alfalfa hay or silage. J. Dairy Sci. 80:1695-1702.

Van Horn, H. H., A. C. Wilkie, W. J. Powers, and R. A. Nordstedt. 1994. Components of dairy manure management systems. J. Dairy Sci. 77:2008-2030.

Van Horn, H. H., G. L. Newton, and W. E. Kunkle. 1996. Ruminant nutrition from an environmental perspective: factors affecting whole-farm nutrient balance. J. Anim. Sci. 74:3082-3101.

van Egmond, K., T. Bresser, and L. Bouwman. 2002. The European nitrogen case. Ambio 31:72-78.

Van Vuuren, A. M., C. J. Van der Koelen, H. Valk, and H. De Visser. 1993. Effects of partial replacement of ryegrass by low protein feeds on rumen fermentation and nitrogen loss by dairy cows. J. Dairy Sci. 76:2982-2993.

Wang, S. J., D. G. Fox, D. J. R. Cherney, L. E. Chase, and L. O. Tedeschi. 2000. Whole-herd optimization with the Cornell Net Carbohydrate and Protein System. III. Application of an optimization model to evaluate alternatives to reduce nitrogen and phosphorus mass balance. J. Dairy Sci. 83:2160-2169.

Wu, Z., L. D. Satter, A. J. Blohowlak, R. H. Stauffacher, and J. H. Wilson. 2001. Milk production, estimated phosphorus excretion, and bone characteristics of dairy cows fed different amounts of phosphorus for two or three years. J. Dairy Sci. 84:1738-1748. 